DOI: 10.2478/ace-2013-0009

\title{
ECONOMICAL REACTIVE POWDER CONCRETE CAST USING AVAILABLE MATERIALS IN NORTH SINAI, EGYPT
}

\author{
NAGEH N. MELEKA ${ }^{1}$, ALAA A. BASHANDY $^{1}$, MOHAMED A. ARAB $^{2}$
}

\begin{abstract}
In this research reactive powder concrete (RPC) was prepared using sand from North Sinai. The mechanical properties of locally cast RPC were investigated and evaluated by studying the effects of using different cement and silica fume contents and new steel fibers' aspect ratios as reinforcement for RPC. Specimens' preparation, curing regimes and testing procedures to evaluate the compressive strength, the modulus of elasticity, the indirect tensile strength and the flexural strength were discussed. A compressive strength of $154.5 \mathrm{MPa}$, indirect tensile strength of $11.98 \mathrm{MPa}$, modulus of elasticity of $45.1 \mathrm{GPa}$ and flexural strength of $30.26 \mathrm{MPa}$ have been achieved for reinforced RPC contains $800 \mathrm{~kg} / \mathrm{m}^{3}$ cement content and silica fume content $30 \%$ of cement weight. The test results showed some improvements by increasing cement and silica fume contentsas well as adding steel fibers on the compressive strength, modulus of elasticity and indirect tensile strength.
\end{abstract}

Key words: Reactive Powder Concrete; Mechanical Properties; Cement Content; Silica Fume Content; Steel Fibers.

\section{INTRODUCTION}

The development of concrete material may be divided into several stages. The first is the traditional normal strength concrete (NSC). The second is the high strength concrete (HSC) that is considered to be the strongest and stiffest cement based material. HSC has a compressive strength of approximately $70 \mathrm{MPa}$, a flexural strength of about $10 \mathrm{MPa}$ and a Young's modulus of 14 to $42 \mathrm{GPa}$. Now, given the improvements on a microscopic scale, the technology of the Reactive Powder Concrete (RPC) is covered by one of many patents in a range known as Ultra High Performance Concretes [1].

RPC represents one of the most recent technological leaps witnessed by the construction industry. It lies at the forefront in terms of innovation, aesthetics and structural efficiency [2]. This new family of materials has compressive strengths of 170 to 230 $\mathrm{MPa}$ and flexural strength of 30 to $50 \mathrm{MPa}$, depending on the type of fibers used [5]. Additionally, it has a tensile strength of between 6 and $13 \mathrm{MPa}$ that is maintained after

1 Civil Engineering Department, Faculty of Engineering, Menoufiya University, Egypt. A.Bashandy: Tel.: 00201003080 108, e-mail: eng_alb@yahoo.com,

2 Civil Engineering Department, Faculty of Engineering Science, Sinai University, Egypt. 
first cracking. The traditional concrete has tensile strengths on the order of 2 to $4 \mathrm{MPa}$ that is lost when cracking occurs [3]. It has also an increased resistance to abrasion, erosion, corrosion and greatly reduced permeability to moisture, chlorides and chemical attack $[4,5]$.

This type of concrete is developed in the 1990s by Bouygues' laboratory in France. It consists of a special concrete where its microstructure is optimized by precise gradation of all particles in the mix to yield maximum density [6]. The development of a reactive powder ductile concrete is possible by the application of a basic principles relating to the composition, mixing and post-set heat curing of the concrete [7].

Usually, there are only four kinds of ingredients composed of the normal strength concrete, which are cement, water, fine aggregates and coarse aggregates. At the very beginning, the easiest way to reach high compressive strength is to reduce the water-cement ratio. Therefore, in HSC, the fifth ingredient, a water reducing agent or super-plasticizer, is indispensable [1].

Ultra high strength concretes are characterized by high silica fume content and a very low water to cement ratio. Granulometry and heat treatment have been optimized to obtain excellent mechanical and durability properties. Reactive Powder Concretes (RPCs) exhibit very high mechanical and durability properties. Their composition is OPC cement, silica fume, aggregates with very fine granulometry sand with average grain diameter of $250 \mu \mathrm{m}$, crushed quartz (average grain diameter of $10 \mu \mathrm{m}$ ). Metallic fibers can be added in order to increase concrete ductility and flexural strength $[8,9]$.

The RPC researchs aimed to define and develope reactive powder ductile concretes. It was conducted with the application of the following basic principles; enhanceing of homogeneity (by elimination of coarse aggregates), increasing of compacted density (by optimization of the granular mixture, and application of pressure before and during setting), enhanceing of the microstructure (by post-set heat-treating), enhanceing of ductility (by incorporating small-sized steel fibers) and maintaining mixing and casting procedures as close as possible to existing practice [7, 10,11].

The absence of coarse aggregate is considered by the inventors to be a key-aspect for the microstructure and the performance of the RPC in order to reduce the heterogeneity between the cement matrix and the aggregate [12]. However, due to the use of very fine sand instead of ordinary aggregate, the cement factor of the RPC is as high as $600-1000 \mathrm{~kg} / \mathrm{m}^{3}$ instead of $300-500 \mathrm{~kg} / \mathrm{m}^{3}$ that are usually used for ordinary concrete. Reactive powder concrete uses extensively the pozzolanic properties of highly refined silica fume and optimization of the Portland cement chemistry to produce the highest strength hydrates [12].

By introducing fine steel fibers, RPC can achieve remarkable flexural strength up to $50 \mathrm{MPa}$. In a typical RPC mixture design, the least costly components of conventional concrete have been basically eliminated or replaced by more expensive elements. The fine sand used in RPC becomes equivalent to the course aggregate of conventional concrete, the Portland cement fills the role of the fine aggregate and the silica fume that of the cement $[13,14]$. 
Advantages of using silica fume in a concrete mix include enhancing compressive strength, bond strength, and abrasion resistance while reducing permeability and thus improving resistance against the corrosion of reinforcement. Consequently the permeability is reduced significantly and resistance against chemical penetration is increased. It fills the voids remaining between cement and quartz powder particles as micro filler [15]. The RPC's mechanical properties are improved by obtaining a denser packing of the solids. The first effect may be explained by so-called 'DSP-concrete' (Densified Systems containing homogeneously arranged ultra-fine Particles). Larger amounts of silica fume (SF) (more than 10\% of the cement weight) are used to 'refine' the particle structure and thereby reduce the total pore volume and the average pore size. The size and spherical geometry of SF particles allow them to fill effectively the voids between the larger and angular cement grains [16].

Silica fume also reacts with calcium hydroxide, thus increase the final strength. Another important effect of the silica fume is the improvement of the interfacial transition zones between binder and aggregates and between binder and steel fibers [17]. Chemically, it reacts with Calcium Hydroxide $(\mathrm{CH})$ to produce additional Calcium Silicate Hydrate (C-S-H). The reaction between hydrated Portland cement compounds and Silica fume produces a very dense microstructure and thus improves the bond between the cement and the aggregates [15].

\section{RESEARCH SIGNIFICANCE}

The present study aims to investigate the feasibility of manufacturing reactive powder concrete RPC mixtures with its ultra high mechanical properties using locally available materials in North Sinai, Egypt. The main variables are; cement content, silica fume content and steel fibers with different aspect ratios $(1 / \mathrm{d})$. In this research, the available sand with its suitable size for this type of concrete and ordinary Portland cement are used instead of using expensive materials such as quartz powder and steel aggregates to produce comparable mixtures as most researchers do. The experimental test program is performed to study the behavior of the RPC under the previous variables in compressive strength, modulus of elasticity, indirect tensile strength and the flexural strength. This research provides data for the researchers concerning with the main properties of RPC manufacturing using economical available materials.

\section{Materials AND EXPERimental PROGRAm}

All tests in this research were carried out in the Construction Materials Laboratory in Civil Engineering Department, Faculty of Engineering Science, Sinai University.

The materials used and how to prepare, cast, cure of testing specimens and testing procedures were discussed in this section. 


\subsection{Materials}

Cement: The cement used was ordinary Portland cement CEM I N52.5, provided by Sinai cement factory. Its chemical and physical characteristics satisfy the Egyptian Standard Specification (E.S.S. 4756-1/2009) [18].

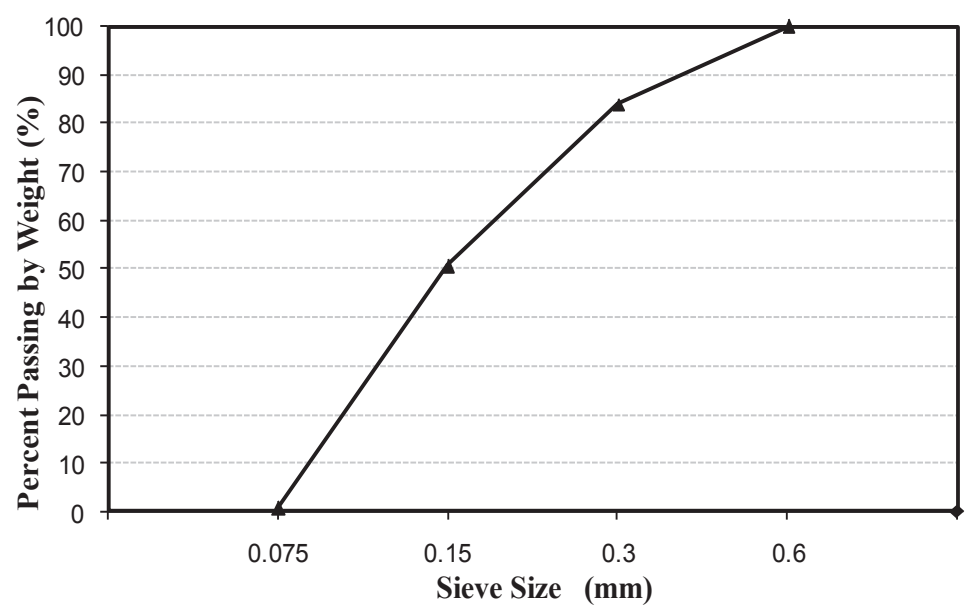

Fig. 1. Grading of sand used.

Fine aggregate: The fine aggregate used in the experimental program was the natural siliceous clean and nearly free from impurities sand with a specific gravity $2.67 \mathrm{t} /$ $\mathrm{m}^{3}$. It was obtained from El-Arish City in North Sinai, Egypt. Its maximum nominal size $(0.6 \mathrm{~mm})$ is suitable to be used in casting ultra high strength concrete UHSC. Physical properties of the used sand are given in Table (1) and its grading is shown in Table (2) and Fig. (2). Sand was sieved over sieve of size $0.6 \mathrm{~mm}$ to discard any impurities.

Table 1

Physical properties of the sand used

\begin{tabular}{|lr|c|}
\hline \multicolumn{2}{|c|}{ Property } & Value \\
\hline Specific gravity & $\left(\mathrm{t} / \mathrm{m}^{3}\right)$ & 2.71 \\
\hline Volumetric weight & $\left(\mathrm{t} / \mathrm{m}^{3}\right)$ & 1.62 \\
\hline Voids ratio & $(\%)$ & $42.1 \%$ \\
\hline Percent of clay, silt and dust & (by weight) & $0.41 \%$ \\
\hline
\end{tabular}


Table 2

Grading of the sand used

\begin{tabular}{|c|c|c|c|c|}
\hline Sieve size $(\mathrm{mm})$ & $0.6 \mathrm{~mm}$ & $0.3 \mathrm{~mm}$ & $0.15 \mathrm{~mm}$ & $0.074 \mathrm{~mm}$ \\
\hline Sieve No. & No. 30 & No. 52 & No. 100 & No. 200 \\
\hline \% Passing & 100 & 86 & 52 & 0.7 \\
\hline
\end{tabular}
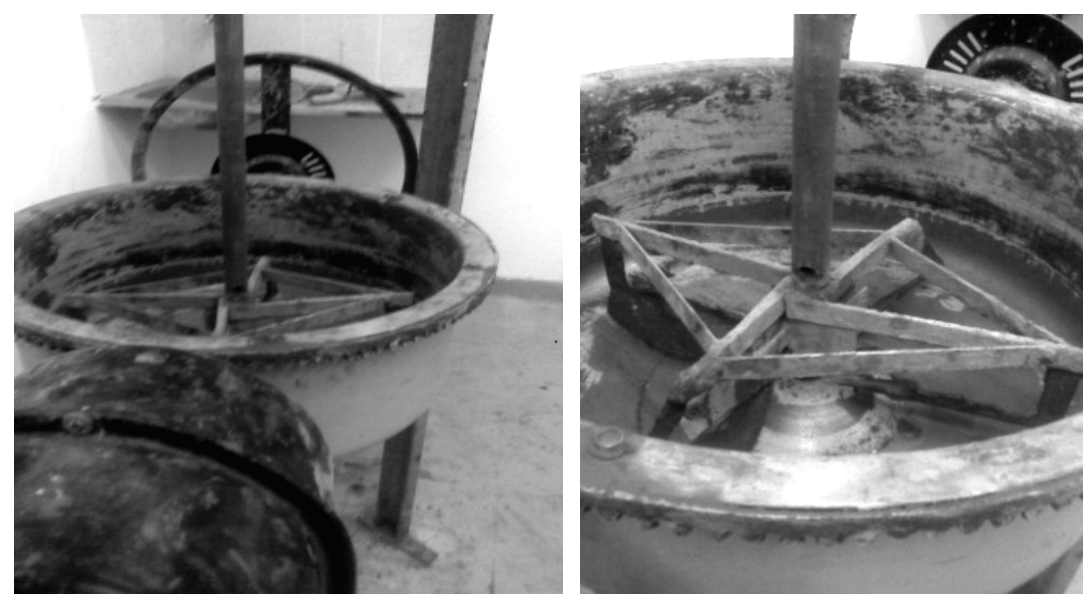

Fig. 2. The used concrete mixer.

Silica fume:It is a waste by-product of silicon and silicon alloys industry consisting mainly of non-combustible amorphous silica $\left(\mathrm{SiO}_{2}\right)$ particles. It was produced by Egyptian Ferro Alloys Corporation (EFACO). The chemical components analysis is shown in Table (3) and the main properties are shown in Table (4). The silica fume used was met the main requirements of ASTM C 1240.

Table 3

The chemical components analysis result of silica fume used

\begin{tabular}{|c|c|c|c|c|c|c|c|c|}
\hline $\begin{array}{c}\text { Chemical } \\
\text { Composition }\end{array}$ & $\mathrm{SiO}_{2}$ & $\mathrm{Al}_{2} \mathrm{O}_{3}$ & $\mathrm{Fe}_{2} \mathrm{O}_{3}$ & $\mathrm{CaO}$ & $\mathrm{MgO}$ & $\mathrm{SO}_{3}$ & $\mathrm{~K}_{2} \mathrm{O}$ & L.O.I. \\
\hline Average (\%) & 95.93 & 0.52 & 0.05 & 0.2 & 0.18 & 0.1 & 0.4 & 2.9 \\
\hline
\end{tabular}

Table 4

Physical properties of the silica fume used

\begin{tabular}{|lc|c|}
\hline \multicolumn{2}{|c|}{ Property } & Value \\
\hline Specific gravity & $\left(\mathrm{t} / \mathrm{m}^{3}\right)$ & 2.20 \\
\hline Bulk density [uncompacted unit weight] & $\left(\mathrm{t} / \mathrm{m}^{3}\right)$ & 0.25 \\
\hline Fineness & $\left(\mathrm{m}^{2} / \mathrm{gm}\right)$ & 23.42 \\
\hline
\end{tabular}


Super-plasticizer: The high-range water-reducing (HRWR) admixtures, often referred to as super-plasticizers, help in increasing the workability of concrete without additional amount of water. In this study a naphthalene sulphonate group based super-plasticizer, supplied by Chemicals for Modern Buildings (CMB) Company, and under the brand name of Addicrete BVF was used. The main properties are shown in Table (5). The used super-plasticizer complies with ASTM C494-Type F [19] and ESS $1899-1$.

Table 5

Mechanical properties of the steel fibers used

\begin{tabular}{|c|c|c|c|c|}
\hline \multirow{2}{*}{ Steel Type } & Yield Stress & Tensile Strength & Elongation & $\begin{array}{c}\text { Modulus of } \\
\text { Elasticity }\end{array}$ \\
\cline { 2 - 5 } & $(M P a)$ & $(M P A)$ & $(\%)$ & $(G P a)$ \\
\hline Steel Fibers & 289 & 389 & 21.6 & 201 \\
\hline
\end{tabular}

Steel fibers: The Fibers are used to increase the tensile capacity and improve the ductility of the RPC. The steel fibers used in this investigation are clean of rust or oil of straight steel wire fibers. The used steel fibers are chopped or cut from steel wires that locally used to tie the steel reinforcement to the stirrups. The steel wires are cut into the desired length which was $13 \mathrm{~mm}$. The fibers used are of diameter $0.8 \pm 0.02 \mathrm{~mm}$ where as the diameter that usually used in nearly all the research in producing UHSC which was $0.2 \mathrm{~mm}$. The aspect ratio of the steel fibers used was 16.25 . This type of fiber is very cheap in comparison with the other types of steel fibers and is available in all markets in Egypt. The properties of the steel fibers used are shown in Table (6).

Table 6

Technical information of Addicrete BVF (As Provided by Manufacturer)

\begin{tabular}{|c|c|c|c|c|c|}
\hline Base & Appearance & Density & $\begin{array}{c}\text { Chloride } \\
\text { content }\end{array}$ & Air entrainment & Compatibility \\
\hline $\begin{array}{c}\text { Naphthaline } \\
\text { sulphonate }\end{array}$ & Brown liquid. & $\begin{array}{c}1.18 \pm 0.01 \\
\mathrm{~kg} / \mathrm{litre}\end{array}$ & Nil & Nil & $\begin{array}{c}\text { All types of } \\
\text { Portland cement }\end{array}$ \\
\hline
\end{tabular}

Water: Clean, drinkable, fresh and free from impurities tap water used for mixing and curing the tested samples according to the Egyptian Code of Practice E.C.P. 203/2007 [20].

\subsection{Mixtures Proportions}

The mixture ratios were based on guidelines and specifications given in several different approaches presented in literature. Mixture proportions used in this test program are summarized in Table (7). The first group is coded by (MS) which casts using steel fibers, while the second group coded by $(\mathrm{M})$ is cast without steel fiber content. 
Table 7

The mixtures proportions used

\begin{tabular}{|c|c|c|c|c|c|c|}
\hline Mix & $\begin{array}{l}\text { Cement } \\
\left(\mathrm{Kg} / \mathrm{m}^{3}\right)\end{array}$ & $\begin{array}{c}\text { Silica Fume } \\
\left(\mathrm{Kg} / \mathrm{m}^{3}\right)\end{array}$ & $\begin{array}{c}\text { Sand } \\
\left(\mathrm{Kg} / \mathrm{m}^{3}\right)\end{array}$ & $\begin{array}{l}\text { Super-plasticizer } \\
\qquad\left(\mathrm{Kg} / \mathrm{m}^{3}\right)\end{array}$ & $\begin{array}{l}\text { Steel Fibers } \\
\left(\mathrm{Kg} / \mathrm{m}^{3}\right)\end{array}$ & $\begin{array}{l}\text { Water } \\
\left(\mathrm{Kg} / \mathrm{m}^{3}\right)\end{array}$ \\
\hline MS-1 & \multirow{3}{*}{700} & 0 & \multirow{9}{*}{1230} & \multirow{3}{*}{70} & \multirow{9}{*}{40} & \multirow{3}{*}{126} \\
\hline MS-2 & & 105 & & & & \\
\hline MS-3 & & 210 & & & & \\
\hline MS-4 & \multirow{3}{*}{750} & 0 & & \multirow{3}{*}{75} & & \multirow{3}{*}{135} \\
\hline MS-5 & & 112.5 & & & & \\
\hline MS-6 & & 225 & & & & \\
\hline MS-7 & \multirow{3}{*}{800} & 0 & & \multirow{3}{*}{80} & & \multirow{3}{*}{144} \\
\hline MS-8 & & 120 & & & & \\
\hline MS-9 & & 240 & & & & \\
\hline M-1 & \multirow{3}{*}{700} & 0 & \multirow{9}{*}{1230} & \multirow{3}{*}{70} & \multirow{9}{*}{0} & \multirow{3}{*}{126} \\
\hline M-2 & & 105 & & & & \\
\hline M-3 & & 210 & & & & \\
\hline M-4 & \multirow{3}{*}{750} & 0 & & \multirow{3}{*}{75} & & \multirow{3}{*}{135} \\
\hline M-5 & & 112.5 & & & & \\
\hline M-6 & & 225 & & & & \\
\hline M-7 & \multirow{3}{*}{800} & 0 & & \multirow{3}{*}{80} & & \multirow{3}{*}{144} \\
\hline M-8 & & 120 & & & & \\
\hline M-9 & & 240 & & & & \\
\hline
\end{tabular}

Cement content that was chosen in this research was 700,750 and $800 \mathrm{~kg} / \mathrm{m}^{3}$. The previous content was chosen to be within the middle of the usual range of the cement content which is ranging between $600 \mathrm{~kg} / \mathrm{m}^{3}$ and $1000 \mathrm{~kg} / \mathrm{m}^{3}$ that was adopted by many researchers as shown previously in the literature.

To investigate the effect of using silica fume on the behaviour of the reactive concrete, three contents of silica fume were used as a percentage of the mixture cement content. The used percentages were $0 \%, 15 \%$ and $30 \%$ of the cement content.

Sand content was the same for all the mixtures in this research. It was chosen to be $1230 \mathrm{~kg} / \mathrm{m}^{3}$. Many researchers like (Lee et al., 2006, 2007) [21, 22] and (Reeves, 2004) [23] choose the fine sand content to be $1020 \mathrm{~kg} / \mathrm{m}^{3}$ but they use quartz powder of $210 \mathrm{~kg} / \mathrm{m}^{3}$ content. In this research we use El-Arish sand with its grading without adding any quartz powder to make the final product of our locally cast reactive concrete more economical so that, $1230 \mathrm{~kg} / \mathrm{m}^{3}$ of sand was chosen.

The used super-plasticizer content was chosen to be one tenth of the average cement content which was $750 \mathrm{~kg} / \mathrm{m}^{3}$ which mean $75 \mathrm{~kg} / \mathrm{m}^{3}$. This content was chosen according 
to the researches done by (Lee et al., 2006, 2007) [21, 22] while other researchers like (Richard and Cheyrezy, 1995) [7] chose the super-plasticizer content to be 0.02 of the cement content but (Jungwirth, 2002) [24] use 0.04 of the cement content while (Matte and Moranville, 1999) [14] and (Yazici et al., 2009) [25] preferred to use about 0.066 of the cement content. In this research the higher content was chosen to make the concrete more workable and to decrease the compaction effort while casting.

Steel fibers are among the main parameters that divide the mixtures into two groups. The first group "MS" was the reactive fiber reinforced concrete with $40 \mathrm{~kg} / \mathrm{m}^{3}$ steel fiber content which was chosen in accordance to Reeves, (2004) [23] (reported that the steel fiber content was ranging between $40 \mathrm{~kg} / \mathrm{m}^{3}$ and $160 \mathrm{~kg} / \mathrm{m}^{3}$ ). The lower limit of $40 \mathrm{~kg} / \mathrm{m}^{3}$ was chosen for more cost saving. The second group " $\mathrm{M}$ " was the plain reactive concrete with no fiber content.

The water/cement ratio was taken between 0.17 and 0.19 for fibered reactive concrete and between 0.15 and 0.17 for plain reactive concrete according to (Richard and Cheyrezy, 1995) [7] and (Cheyrezy et al., 1995) [8]. In this research the w/c ratio was chosen to be 0.18 for all the 18 mixtures.

\subsection{Mixing Casting and Curing Processes}

The mixing process was performed using a ring concrete mixer of 15 liters capacity that shown in Figure (2). The mixture components weighted carefully then, sand and cement mixed to obtain homogenous mix. Silica fume and steel fibers (for mix contains steel fibers) added to the mix. The water and the super plasticizer mixed then added to the dry contents in the drum then mixed till the mixture is in suitable consistency to be cast (time differ from mix to the other according to mixtures components).

The compaction process was performed by concrete vibrator which was slowly insert and was not allow being rest on or touching the bottom or sides of the mould. After vibrating rod strokes were distributed uniformly over the cross section of the mould to ensure the best compaction especially for the final layer. After the compaction process, the excess concrete was removed.Special care for finishing faces was taken into consideration by striking them off with trowel especially cylindrical specimens.

Specimens were demoulded 24 hours after casting and water cured at about $75^{\circ} \mathrm{C}$ for 3 days then in $25^{\circ} \mathrm{C}$ for another 3 days after those specimens were gotten out from the water to a dry place till the age of testing. For maintaining uniform curing all the specimens were cured in the same curing tanks.

\subsection{Concrete SAmples}

Samples were divided into three groups. (i) Standard cubes of dimensions $100 \times 100 \times 100 \mathrm{~mm}$ for measuring the compressive strength, (ii) cylinders of $100 \mathrm{~mm}$ diameter and $200 \mathrm{~mm}$ height for measuring the indirect tensile strength and the modulus of elasticity and (iii) prisms of $100 \times 100 \times 500 \mathrm{~mm}$ to measure the flexural strength. 


\subsection{Testing Procedures and Equipments}

All tests in this research were carried out to investigate the main properties of RPC samples as reported in this section.

Compressive strength test: was carried out to determine the compressive strength of specimens of concrete cubes. A $2000 \mathrm{KN}$ capacity compression testing machine was used.

Modulus of elasticity test: The modulus of elasticity of cylindrical specimens was determined. Stresses and corresponding strains were evaluated and average values were calculated. A $2000 \mathrm{KN}$ capacity compression testing machine was used to apply a compressive axial load and Compress meter (dial gauge with accuracy $0.01 \mathrm{~mm}$ and a maximum capacity of $10 \mathrm{~mm}$ ) was used.

Tensile strength test: Indirect tension test (splitting method) was performed to determine the tensile strength of concrete mixes using cylindrical specimens of RPC. A $2000 \mathrm{KN}$ capacity compression testing machine was used.

Prism Flexural Test: This test method evaluates the flexural strength of the tested prism specimens using a flexure testing machine of $150 \mathrm{KN}$ capacity.

\section{TEST RESULTS AND DISCUSSIONS}

The properties which were taken into consideration in this research were the compressive strength, the modulus of elasticity, the indirect tensile strength and the flexural strength at the age of 7 and 28 days of the RPC samples.Table (8) shows the mechanical properties of RPC mixes.

Table 8

The mechanical properties of the RPC mixtures used

\begin{tabular}{|c|c|c|c|c|c|c|c|c|}
\hline \multirow{2}{*}{ Mix } & \multicolumn{2}{|c|}{$\begin{array}{c}\text { Compressive Strength } \\
(\mathrm{MPa})\end{array}$} & \multicolumn{2}{c|}{$\begin{array}{c}\text { Modulus of Elasticity } \\
(\mathrm{GPa})\end{array}$} & \multicolumn{2}{c|}{$\begin{array}{c}\text { Tensile Strength } \\
(\mathrm{MPa})\end{array}$} & \multicolumn{2}{c|}{$\begin{array}{c}\text { Flexural Strength } \\
(\mathrm{MPa})\end{array}$} \\
\cline { 2 - 10 } & 7 days & 28 days & 7 days & 28 days & 7 days & 28 days & 7 days & 28 days \\
\hline MS-1 & 56.5 & 72.5 & 9.65 & 22.91 & 4.49 & 5.65 & 11.05 & 13.89 \\
\hline MS-2 & 90.0 & 100.0 & 25.53 & 27.92 & 7.80 & 8.06 & 17.35 & 17.99 \\
\hline MS-3 & 110.0 & 119.0 & 34.36 & 35.45 & 9.81 & 9.96 & 23.67 & 24.51 \\
\hline MS-4 & 68.0 & 75.5 & 19.07 & 24.43 & 6.75 & 7.67 & 14.84 & 17.64 \\
\hline MS-5 & 109.5 & 115.0 & 30.15 & 31.23 & 9.48 & 9.73 & 20.36 & 21.05 \\
\hline MS-6 & 135.0 & 138.5 & 39.88 & 40.95 & 10.77 & 10.97 & 27.16 & 27.61 \\
\hline MS-7 & 74.0 & 78.5 & 23.58 & 25.23 & 8.51 & 8.93 & 17.89 & 19.98 \\
\hline MS-8 & 124.0 & 128.5 & 34.05 & 34.91 & 10.43 & 10.65 & 21.76 & 23.22 \\
\hline MS-9 & 151.5 & 154.5 & 44.38 & 45.10 & 11.80 & 11.98 & 29.46 & 30.26 \\
\hline
\end{tabular}


Table 8

\begin{tabular}{|c|c|c|c|c|c|c|c|c|}
\hline \multirow{2}{*}{ Mix } & $\begin{array}{c}\text { Compressive Strength } \\
(\mathrm{MPa})\end{array}$ & \multicolumn{2}{c|}{$\begin{array}{c}\text { Modulus of Elasticity } \\
(\mathrm{GPa})\end{array}$} & \multicolumn{2}{c|}{$\begin{array}{c}\text { Tensile Strength } \\
(\mathrm{MPa})\end{array}$} & \multicolumn{2}{c|}{$\begin{array}{c}\text { Flexural Strength } \\
(\mathrm{MPa})\end{array}$} \\
\cline { 2 - 10 } & 7 days & 28 days & 7 days & 28 days & 7 days & 28 days & 7 days & 28 days \\
\hline M-1 & 55.0 & 67.0 & 9.23 & 19.42 & 3.97 & 4.98 & 4.75 & 6.12 \\
\hline M-2 & 88.0 & 95.5 & 24.15 & 26.28 & 5.91 & 6.09 & 6.93 & 7.50 \\
\hline M-3 & 106.0 & 114.0 & 30.81 & 31.58 & 7.59 & 7.72 & 9.15 & 9.49 \\
\hline M-4 & 65.5 & 74.0 & 17.25 & 21.68 & 5.42 & 6.08 & 6.24 & 7.48 \\
\hline M-5 & 106.0 & 111.5 & 27.92 & 28.46 & 8.35 & 8.56 & 9.49 & 9.85 \\
\hline M-6 & 128.5 & 134.0 & 34.52 & 35.44 & 9.37 & 9.50 & 12.88 & 13.31 \\
\hline M-7 & 73.0 & 76.0 & 21.12 & 22.33 & 7.83 & 8.12 & 8.39 & 8.95 \\
\hline M-8 & 121.0 & 125.0 & 30.98 & 31.53 & 9.20 & 9.44 & 10.60 & 10.88 \\
\hline M-9 & 148.5 & 152.0 & 40.13 & 40.99 & 10.87 & 10.99 & 14.41 & 14.73 \\
\hline
\end{tabular}

\subsection{Compressive Strength Test Results and Discussion}

The compressive strength test results are shown in Table (8) and Figures (3) to (5). The compressive strength test results show that there is a great positive effect of increasing silica fume content on the compressive strength of RPC at 7 and 28 days tests of samples "M" and "MS" regardless cement content.

Increasing silica fume content improves the compressive strength at the age of 7 days by about $59-67 \%$ and $94-104 \%$ for $15 \%$ and $30 \%$ silica fume content respectively for different cement contents compared to samples without silica fume content for group "MS" while those values become about $60-65 \%$ and $92-103 \%$ for $15 \%$ and $30 \%$ silica fume content respectively for "M" group. After 28 days, the compressive strength increased by about $37-65 \%$ and $65-96 \%$ for $15 \%$ and $30 \%$ silica fume content respectively compared to samples without silica fume content for group "MS" while those values become about $42-65 \%$ and $70-100 \%$ for $15 \%$ and $30 \%$ silica fume content respectively for " $\mathrm{M}$ " group. The main reason for the increase in the compressive strength is due to the physical effect of the finer silica fume grains that allows denser packing within the cement particles and improves the concrete microstructure which leads to increase in the reactive concrete compressive strength. The previous results were coincident with the results of (Richard and Cheyrezy, 1995) [7] and (Shihada and Arafa, 2010) [15]. 


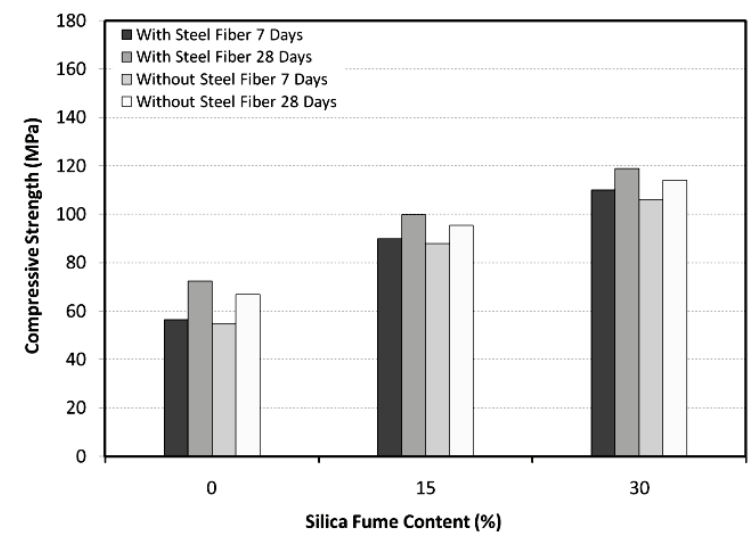

Fig. 3. Compressive strength for samples of $700 \mathrm{~kg} / \mathrm{m}^{3}$ cement content.

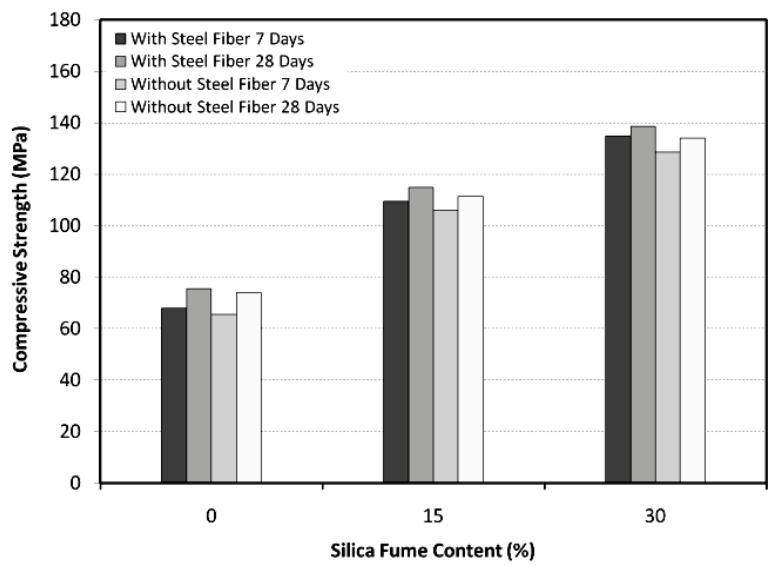

Fig. 4. Compressive strength for samples of $750 \mathrm{~kg} / \mathrm{m}^{3}$ cement content.

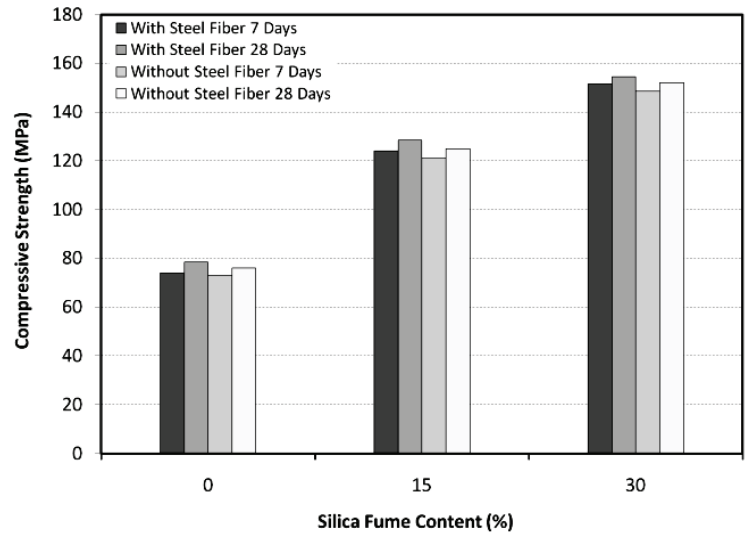

Fig. 5. Compressive strength for samples of $800 \mathrm{~kg} / \mathrm{m}^{3}$ cement content. 
Increasing the cement content increases the compressive strength of RPC samples' at age of 7 and 28 days for samples "M" and "MS" despite the silica fume content. Increasing cement content improves the compressive strength at 7 days tests of group "MS" by about $20-22 \%$ and $30-37 \%$ for $750 \mathrm{~kg} / \mathrm{m}^{3}$ and $800 \mathrm{~kg} / \mathrm{m}^{3}$ compared to cement content of $700 \mathrm{~kg} / \mathrm{m}^{3}$ while for group " $\mathrm{M}$ " increased by about $19-21 \%$ and $32-47 \%$ for $750 \mathrm{~kg} / \mathrm{m}^{3}$ and $800 \mathrm{~kg} / \mathrm{m}^{3}$ cement content compared to "M" samples of $700 \mathrm{~kg} / \mathrm{m}^{3}$ cement content. Results of 28 days tests of group "MS" show that, compressive strength increased by about $4-16 \%$ and $8-29 \%$ for $750 \mathrm{~kg} / \mathrm{m}^{3}$ and $800 \mathrm{~kg} / \mathrm{m}^{3}$ with respect to 700 $\mathrm{kg} / \mathrm{m}^{3}$ cement content for different values of silica fume content. Those values increased by about $10-17 \%$ and $13-33 \%$ for $750 \mathrm{~kg} / \mathrm{m}^{3}$ and $800 \mathrm{~kg} / \mathrm{m}^{3}$ for group " $\mathrm{M}$ " for different values of silica fume content. The reason for the increase in the compressive strength is very clear because the cement is the main bonding material and any increase in its content leads to an increase in the compressive strength. The changing in cement content affected the compressive strength but with less effect than the effect of the changing in silica fume content.

Reinforcing the reactive powder concrete with the used steel fibers type and content has a slight positive effect on the compressive strength at 7 and 28 days tests of RPC samples. Adding steel fibers content of $40 \mathrm{~kg} / \mathrm{m}^{3}$ improves the compressive strength by about $1.3-5.1 \%$ for 7 days tests and $1.6-8.2 \%$ for 28 days tests compared to plain reactive concrete. The reason of this slight effect may be due to adding of small percentage of steel fibers content which was $40 \mathrm{~kg} / \mathrm{m}^{3}$. The enhancement due to steel fiber adding is acceptable when compared to the results obtained by ((Maroliya and Modhera, 2010) [26] that reported that the increase in the compressive strength of RPC reinforced by steel fibers at $2 \%$ volume (about $160 \mathrm{~kg} / \mathrm{m}^{3}$ ) was $30 \%$ higher than that of the plain reactive concrete.

The age effect on the compressive strength of the RPC is shown in Figures (3) to (5). It is shown that the increase of the 28 days compressive strength with respect to 7 days compressive strength is affected by the cement and silica fume content. When the cement and silica fume content increase the enhancement of the compressive strength is decreased and that is shown in the percentage of the compressive strength increasing which was about $28 \%$ for samples without silica fume and $700 \mathrm{~kg} / \mathrm{m}^{3}$ cement content and was about $1.98 \%$ at $30 \%$ silica fume and $800 \mathrm{~kg} / \mathrm{m}^{3}$ cement content. The age effect on the compressive strength was little affected by reinforcing the reactive concrete. The previous results agree with conclusions of the research carried out by (Habel et. al., 2006) [17].

\subsection{Modulus of Elasticity Test Results and Discussion}

The modulus of elasticity test results is shown in Table (8) and Figures (6) to (8). The increase in the silica fume content has a remarkable helpful effect on the modulus of elasticity of RPC samples at the tests of 7 and 28 days for groups "M" and "MS" regardless cement content. 


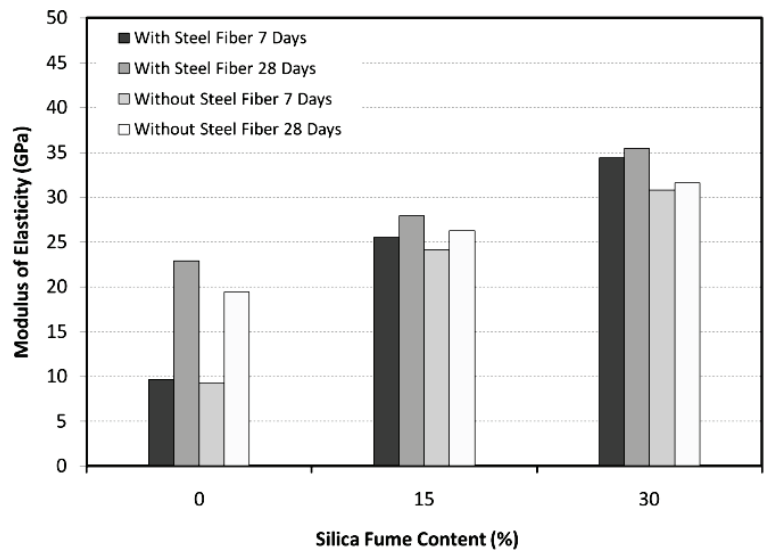

Fig. 6. Modulus of elasticity for samples of $700 \mathrm{~kg} / \mathrm{m}^{3}$ cement content.

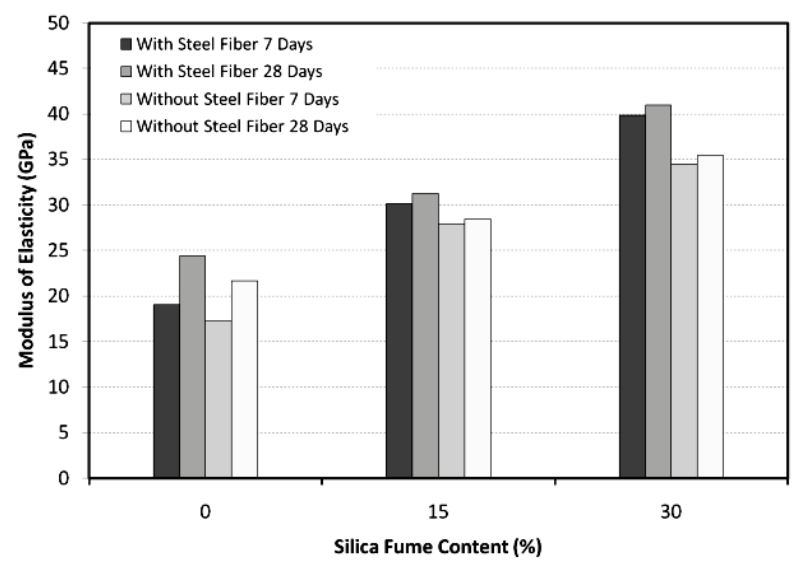

Fig. 7. Modulus of elasticity for samples of $750 \mathrm{~kg} / \mathrm{m}^{3}$ cement content.

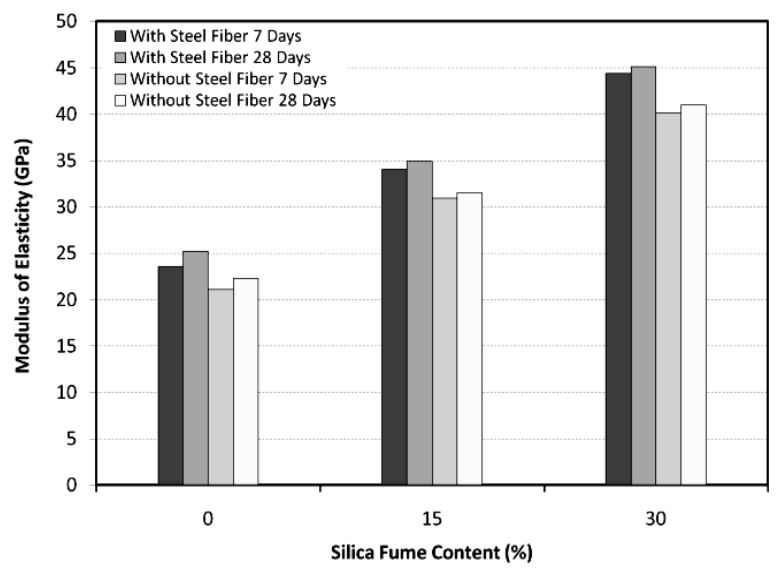

Fig. 8. Modulus of elasticity for samples of $800 \mathrm{~kg} / \mathrm{m}^{3}$ cement content. 
At 7 days tests, the modulus of elasticity values were increased by about $44-164 \%$ for $15 \%$ silica fume content and by about $88-256 \%$ for $30 \%$ silica fume depending on cement content (as cement increase elasticity decreased) for "MS" and "M" groups regardless fiber content. For 28 days tests, modulus of elasticity values were increased by about $21-41 \%$ and $54-83 \%$ for $15 \%$ and $30 \%$ silica fume content compared to those without silica fume content apart from fiber content. The increase of the modulus of elasticity is due to increasing the compressive strength. The maximum modulus of elasticity was recorded as $45.1 \times 10^{3} \mathrm{MPa}$ at $800 \mathrm{~kg} / \mathrm{m}^{3}$ cement content, $30 \%$ silica fume content for sample "MS-9" while that value decreased to $40.99 \times 10^{3} \mathrm{MPa}$ for sample "M-9" which satisfies results of (Prabha et. al., 2010) [2].

By increasing the cement content, the modulus of elasticity values of groups "M" and "MS" increased apart from the silica fume content at 7 and 28 days tests.

Increasing cement content improves the modulus of elasticity. At 7 days tests, values increased by about $97-144 \%, 18-33 \%$ and $16-29 \%$ for samples with silica fume contents 0,15 and $30 \%$ respectively for $750 \mathrm{~kg} / \mathrm{m}^{3}$ and $800 \mathrm{~kg} / \mathrm{m}^{3}$ cement content with respect to mixes with $700 \mathrm{~kg} / \mathrm{m}^{3}$ cement content. At tests of 28 days, values increased by values up to about $15 \%$ for "MS- 6 " and $27 \%$ for "MS-9" compared to samples of $700 \mathrm{~kg} / \mathrm{m}^{3}$ cement content. The increase in cement content affects the modulus of elasticity at 7 and 28 days tests especially for samples without silica fume content. Increase in cement content has a remarkable increase in the modulus of elasticity values due to the effect of the bonding materials especially at 7 days age.

Reinforcing using steel fibers with the used type and content had a positive effect on the modulus of elasticity at 7 and 28 days age of RPC samples. The positive effect on the modulus of elasticity of group "MS" was ranging between 4-15\% compared to group " $\mathrm{M}$ " at the 7 days age, while it was ranging between $6 \%$ to $17 \%$ for group "MS" compared to group " $\mathrm{M}$ " at the 28 days tests. The previous results are acceptable when compared to results obtained by (Prabha et. al., 2010) [2], who report that the increase in the modulus of elasticity of the RPC using steel fiber as $2 \%$ of cement content was about 24\% higher than plain RPC. The positive effect on the modulus of elasticity is a proof to the helpful and apparent effect of the used steel fibers.

Test results of the modulus of elasticity of RPC have shown that the increasing of 28 days modulus of elasticity with respect to 7 days values is affected by the cement and silica fume content. When the cement and silica fume content increase, the modulus of elasticity is decreased. The age effect on the modulus of elasticity is slightly affected by reinforcing the reactive concrete with steel fibers especially for samples without silica fume content.

\subsection{Tensile Strength Test Results and Discussion}

The indirect tensile strength test results are shown in Table (8) and ures (9) to (11). The increasing in the silica fume content has affect positively the indirect tensile strength at 7 and 28 days reactive concrete age for reinforced and unreinforced reactive concrete 


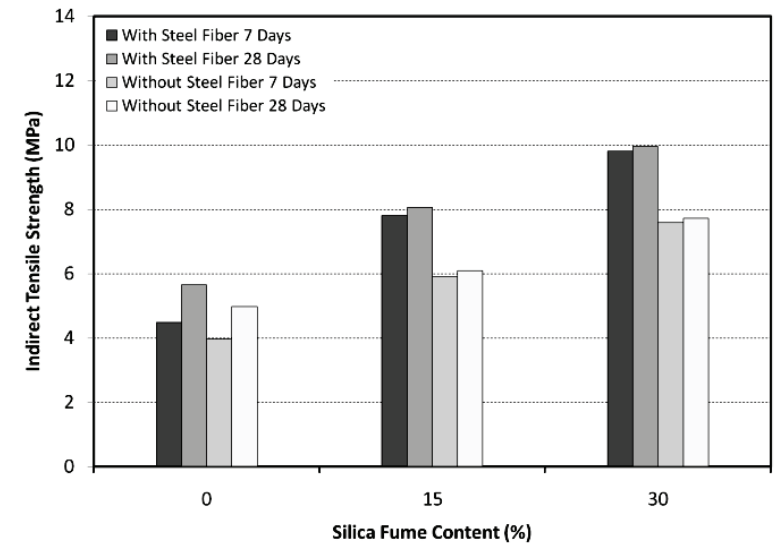

Fig. 9. Indirect tensile strength for samples of $700 \mathrm{~kg} / \mathrm{m}^{3}$ cement content.

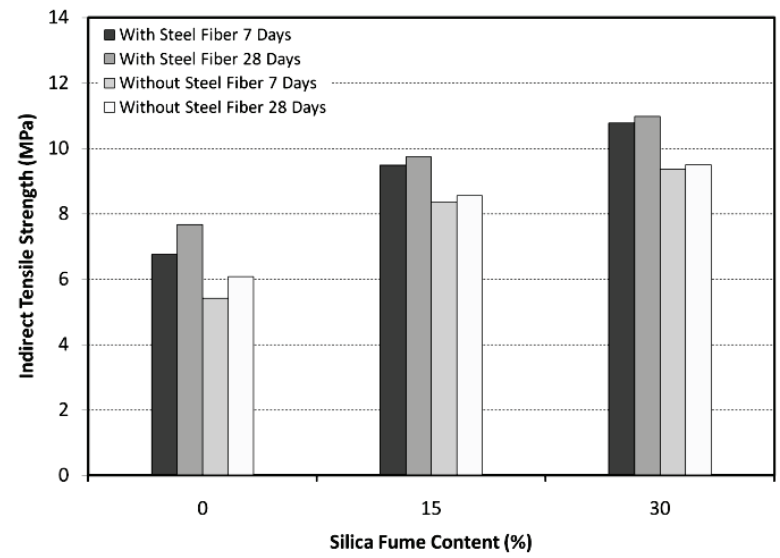

Fig. 10. Indirect tensile strength for samples of $750 \mathrm{~kg} / \mathrm{m}^{3}$ cement content.

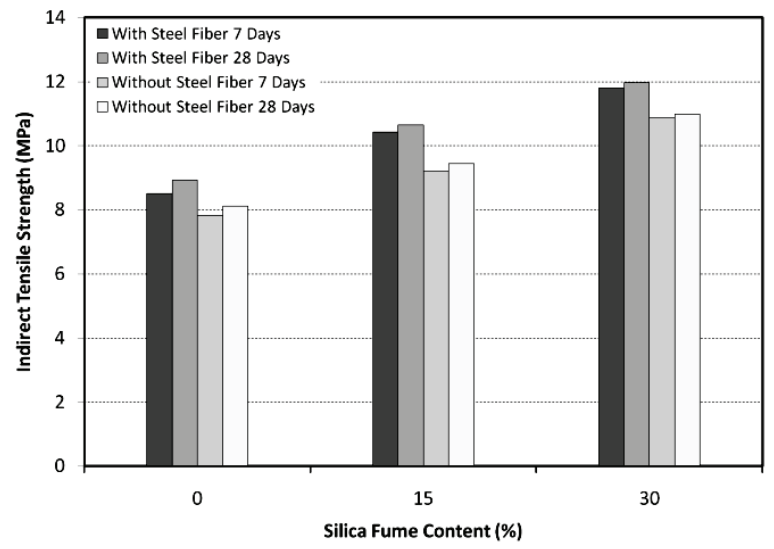

Fig. 11. Indirect tensile strength for samples of $800 \mathrm{~kg} / \mathrm{m}^{3}$ cement content. 
without considering the cement content. At 7 days RPC samples' age the indirect tensile strength was increased by about $45 \%$ for $15 \%$ silica fume content and $70 \%$ for $30 \%$ silica fume content samples with respect to the indirect tensile strength of samples without silica fume content. In the case of 28 days indirect tensile strength, increasing by about $30 \%$ for $15 \%$ silica fume content and $50 \%$ for $30 \%$ silica fume content samples with respect to the indirect tensile strength of samples without silica fume content was observed. The previous results shows that by increasing the silica fume content, the ductility of the reactive concrete increase and that tends to improve in the tensile strength of the reactive concrete. The previous results are coincides with results of (Habel et. al., 2006) [17] who report that there is a beneficial effect of the silica fume reaction on the tensile strength.

The increasing in the cement content has a positive effect on the tensile strength at 7 and 28 days reactive powder concrete samples' age for reinforced and unreinforced reactive concrete without considering the silica fume content. At 7 days RPC samples' age the indirect tensile strength was increased by about $30 \%$ for $750 \mathrm{~kg} / \mathrm{m}^{3}$ cement content and $57 \%$ for $800 \mathrm{~kg} / \mathrm{m}^{3}$ cement content samples with respect to the indirect tensile strength of samples with $700 \mathrm{~kg} / \mathrm{m}^{3}$ cement content. The indirect tensile strength at the age of 28 days for the RPC samples was increased by about $25 \%$ for $750 \mathrm{~kg} / \mathrm{m}^{3}$ cement content and $45 \%$ for $800 \mathrm{~kg} / \mathrm{m}^{3}$ cement content samples with respect to the indirect tensile strength of samples with $700 \mathrm{~kg} / \mathrm{m}^{3}$ cement content. The increasing in the indirect tensile strength was related to the increasing in the compressive strength.

There was a positive effect on the indirect tensile strength at 7 and 28 days age of reactive powder concrete samples' age by reinforcing with steel fibers with the used type and content. The effect on the indirect tensile strength was ranging between $8.6 \%$ to $32.2 \%$ for 7 days age and $9.0 \%$ to $32.5 \%$ for 28 days age increasing of the reinforced reactive concrete with respect to the plain reactive concrete. (Maroliya and Modhera, 2010) [26] reported that reinforcement was significantly affecting the splitting tensile strength with $50 \%$ higher than plain reactive concrete that is higher than results shown previously but it is acceptable because the adding steel fibers content was of small percentage.

Results indicated from indirect tensile strength test executed on 7 and 28 days reactive powder concrete age shows that the increasing of 28 days indirect tensile strength with respect to 7 days indirect tensile strength was affected by the cement and silica fume content. When the cement and silica fume content increase the increasing in the indirect tensile strength was decreased and that was shown in the percentage of the indirect tensile strength increasing which was about $25.0 \%$ for samples without silica fume and $700 \mathrm{~kg} / \mathrm{m}^{3}$ cement content and was about $1.5 \%$ at $30 \%$ silica fume and 800 $\mathrm{kg} / \mathrm{m}^{3}$ cement content. The age effect on the indirect tensile strength did not affected by reinforcing the reactive concrete. 


\subsection{Flexural Strength Test Results and Discussion}

The flexural strength test results are shown in Table (8) and Figures (12) to (14). The flexural strength test results show that the increasing in silica fume content has a valuable positive effect of on the flexural strength of the RPC at 7 days age for reinforced and unreinforced samples without considering the cement content. At 7 days RPC samples' age the flexural strength was increased by about $40 \%$ for $15 \%$ silica fume content and $90 \%$ for $30 \%$ silica fume content samples with respect to the flexural strength of samples without silica fume content. In the case of 28 days flexural strength, increasing by about $24 \%$ for $15 \%$ silica fume content and $64 \%$ for $30 \%$ silica fume content samples with respect to the flexural strength of samples without silica fume content was recorded. The previous results are another evidence for the positive effect of adding silica fume on the ductility of the reactive concrete which leads to better behaviour in bending.

The increasing in the cement content increases the flexural strength at 7 and 28 days RPC samples' age for reinforced and unreinforced RPC without considering the silica fume content. At 7 days RPC samples' age the flexural strength was increased by about $30 \%$ for $750 \mathrm{~kg} / \mathrm{m}^{3}$ cement content and $50 \%$ for $800 \mathrm{~kg} / \mathrm{m}^{3}$ cement content samples with respect to the flexural strength of samples with $700 \mathrm{~kg} / \mathrm{m}^{3}$ cement content. The flexural strength at the age of 28 days for the RPC samples was increased by about $25 \%$ for $750 \mathrm{~kg} / \mathrm{m}^{3}$ cement content and $40 \%$ for $800 \mathrm{~kg} / \mathrm{m}^{3}$ cement content samples with respect to the flexural strength of samples with $700 \mathrm{~kg} / \mathrm{m}^{3}$ cement content.

By reinforcing the reactive powder concrete with steel fibers there is a great and valuable positive effect on the flexural strength at 7 and 28 days RPC samples' age. The increasing of the flexural strength was ranging between $100 \%$ and $160 \%$ of the reinforced reactive powder concrete prisms with respect to the plain reactive powder concrete prisms. The addition of fibers significantly increases the flexural strength of RPC and these results were coincident with results of (Maroliya and Modhera, 2010) [26]. Increasing of the flexural strength for the reinforced reactive concrete with respect to the plain reactive concrete was evidence to the successful chosen of the used steel fiber type.

From Table (8) and Figures (12) to (14), it is shown that the increasing of 28 days flexural strength with respect to 7 days flexural strength was affected by the increasing of the cement and silica fume content. The age effect on the flexural strength did not affected by reinforcing the reactive concrete. The previous results were coincident with conclusions of the research that was carried out by (Hong et al., 2010) [27] who reported that the strength at 7 days was almost equal to the strength at 28 days except for reactive concrete of samples without silica fume content which has a remarkable age effect on the flexural strength of the reactive concrete. 


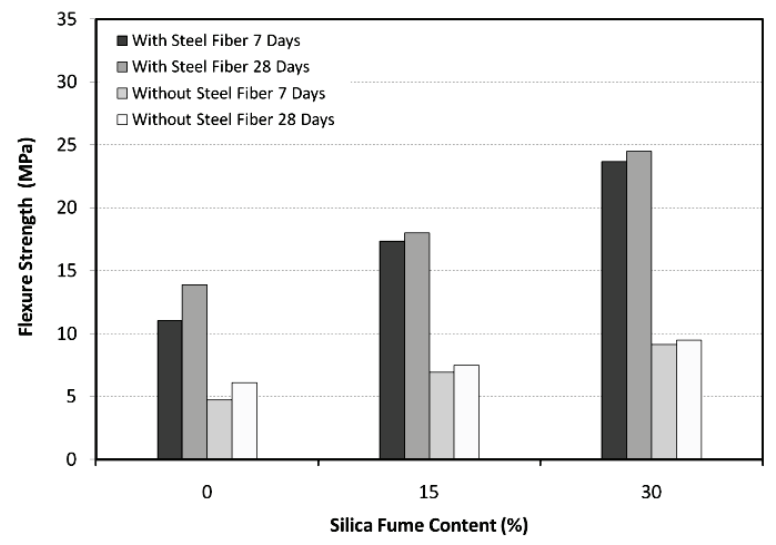

Fig. 12. Flexural strength for samples of $700 \mathrm{~kg} / \mathrm{m}^{3}$ cement content.

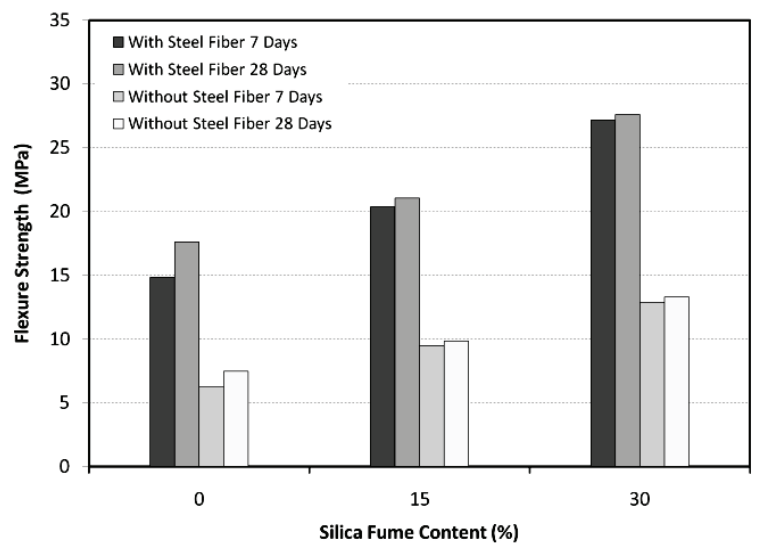

Fig. 13. Flexural strength for samples of $750 \mathrm{~kg} / \mathrm{m}^{3}$ cement content.

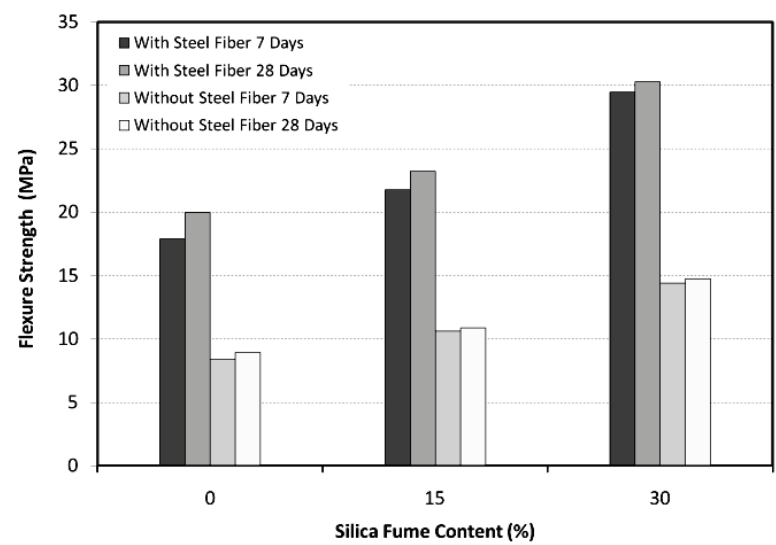

Fig. 14. Flexural strength for samples of $800 \mathrm{~kg} / \mathrm{m}^{3}$ cement content. 


\subsection{ECONOMIC STUdY}

From the economic point of view (without taking in to consideration labour costs), using Sinai sand is considered less cost compared to quartz powder used by other researchers $[7,8,10,11,14]$. Sinai sand costs about $1.5 \$ / 1 \mathrm{~m}^{3}$ while quartz sand powder costs about $50 \$ / 1 \mathrm{~m}^{3}$. Other componants of RPC are the same as other researches. Plain RPC costs about $250 \$ / \mathrm{m}^{3}$. Thatleds to less cost by about $10 \%$.

In case of using steel fibers, the steel fiber reinforced RPC costs about $340 \$ / 1 \mathrm{~m}^{3}$ with increasing in cost by about $36 \%$ comparing to plain RPC.

When comparing the plain RPC to the plain ordinary concrete (compressive strength=30 MPa), RPC costs about $250 \$ / \mathrm{m}^{3}$ while ordinary concrete costs about $70 \$ / \mathrm{m}^{3}$. That meaning the RPC costs about 3.5 times larger than ordinary concrete but having 5 times compressive strength values comparing to plain ordinary concrete.

\section{Conclusions}

Based on the results obtained from the current research, the following main conclusions can be summarized:

1. Ultra high strength concrete could be produced effectively using cheap available materials in North Sinai, Egypt.

2. A compressive strength of $154.5 \mathrm{MPa}$, indirect tensile strength of $11.98 \mathrm{MPa}$, modulus of elasticity of $45.1 \mathrm{GPa}$ and flexural strength of $30.26 \mathrm{MPa}$ were approached for steel fibers reactive concrete samples of $800 \mathrm{~kg} / \mathrm{m}^{3}$ cement content and $30 \%$ silica fume/cement (mix M9).

3. Increasing of the studied properties of the reactive concrete samples at the 28 days results with respect to that of 7 days age was very small except in the case of samples that have no silica fume content it has a positive effect.

4. Increasing silica fume contents improves the compressive strength, modulus of elasticity, tensile strength and flexural strength values at different RPC ages.

5. It is recommended to use silica fume content up to $30 \%$ of the cement content. Increasing silica fume content improves the compressive strength, modulus of elasticity, tensile strength and flexural strength values at different RPC ages.

6. Increasing cement contents enhance the compressive strength, modulus of elasticity, tensile strength and flexural strength values at different RPC ages.

7. Adding steel fibers content of $40 \mathrm{~kg} / \mathrm{m}^{3}$ improves the compressive strength at the age of 7 and 28 days by about $7 \%$ with respect plain RPC. It also improves the modulus of elasticity at the age of 7 and 28 days by about $18 \%$ compared to plain RPC and improves the tensile strength at the age of 28 days by about $30 \%$. Flexural strength values improve at the age of 7 and 28 days by about $190 \%$.

8. It is recommended to use steel fibers as an enhancing material to RPC. 
Finally, it can produce an economic RPC using locally available materials in North Sinai, Egypt, in order to manufacturing a pre-cast ultra high strength concrete with ultra mechanical properties.

\section{REFERENCES}

1. Xiaoa, J., Schneiderb, H., Donneckeb, C., Konigb G.: Wedge Splitting Test on Fracture Behaviour of Ultra High Strength Concrete. Construction and Building Materials. 18, 359-365 (2004).

2. Prabha, S.L., Dattatreya, J.K., Neelamegam, M., Seshagirirao, M.V.: Study on Stress-Strain Properties of Reactive Powder Concrete under Uniaxial Compression, International Journal of Engineering Science and Technology. 2 (11), 6408-6416 (2010).

3. Washer, G., Fuchs, P., Graybeal, B.: Elastic Properties of Reactive Powder Concrete, International Symposium on Non-Destructive Testing in Civil Engineering (NDT-CE 2003)", Germany (2003)

4. Abdelrazig, B.: Properties and Applications of CeraCem Ultra High Performance Self Compacting Concrete, Proceeding of the International Conference on Construction and Building Technology. 20, 217-226 (2008).

5. Moallem, M.R.: Flexural Redistribution in Ultra-High Performance Concrete Lab Specimens, M.Sc. Thesis, Russ College of Engineering and Technology, Ohio University, USA (2010).

6. Emerging Construction Technologies: Purdue University web. http://rebar.ecn.purdue.edu/ect/links/ technologies/Civil/Reactive.aspx (2011) Accessed 11 April 2011.

7. Richard, P., Cheyrezy, M.: Composition of reactive powder concrete, Cement and Concrete Research 5(7), 1501- 1511 (1995).

8. Cheyrezy, M., Maret, V., Frouin, L.: Micro structural analysis of RPC (Reactive Powder Concrete), Cement and Concrete Research 25(7), 1491-1500 (1995).

9. JSCE No. 9: Guidelines for Concrete, Recommendation for design and construction of ultra high strength fiber reinforced concrete structures (Draft), Japan Society of Civil Engineers (JSCE), Japan (2006).

10. Ipek, M., Yilmaz, K., Sümer, M., Saribiyik, M.: Effect of pre-setting pressure applied to mechanical behaviours of reactive powder concrete during setting phase, Construction and Building Materials 25(1), 61-68 (2011).

11. Yang, I.H., John, C., Kim, B.S.: Structural behavior of ultra high performance concrete beams subjected to bending, Engineering Structures Journal 32, 3478-3487 (2010).

12. Collepardi, S., Coppola, L., Troli, R., Collepardi, M.: Mechanical Properties of Modified Reactive Powder Concrete, Proceedings of the Fifth Conference on Super-plasticizers and Other Chemical Admixtures in Concrete, ACI Publication SP-173, Rome, Italy 1-21 (1997).

13. Jooss, M.: Leaching of Concrete under Thermal Influence, Otto-Graf-Journal 12, 51-68 (2001).

14. Matte, V., Moranville, M.: Durability of Reactive Powder Composites: influence of silica fume on the leaching properties of very low water/binder pastes, Cement and Concrete Composites 21, 1-9 (1999)

15. Shihada, S., Arafa, M.: Effects of silica fume, ultrafine and mixing sequences on properties of ultra high performance concrete, Asian Journal of Materials Science, 2(3), 137-146 (2010).

16. Rashid, M.A., Mansur, M.A.: Considerations in producing high strength concrete, Journal of Civil Engineering (IEB) 37(1), 53-63 (2009).

17. Habel, K., Viviani, M., Denarié, E., Brühwiler, E.: Development of the mechanical properties of an Ultra-High Performance Fiber Reinforced Concrete (UHPFRC), Cement and Concrete Research 36, 1362-1370 (2006).

18. E.S.S. 4756-1/2009: Ordinary Portland Cement, Egyptian Standard Specification, Egypt (2009). 
19. ASTM C 494-03: Chemical Admixtures, American Society for Testing and Materials (ASTM), ASTM International, Philadelphia, USA (2003).

20. E.C.P. 203/2007: Design and Construction for Reinforced Concrete Structures, Egyptian Code of Practice, Research Centre for Houses Building and Physical Planning, Cairo, Egypt (2007).

21. Lee, M.G., Kan, Y.C., Chen, K.C.: A Preliminary Study of RPC for Repair and Retrofitting Materials, Journal of the Chinese Institute of Engineers 29(6), 1099-1103 (2006).

22. Lee, M.G., Wang, Y.C., Chiu, C.T.: A preliminary study of reactive powder concrete as a new repair material, Construction and Building Materials 21, 182-189 (2007).

23. Reeves, E.: Structural Reliability of Ultra-High Performance Concrete in Flexure, M.Sc. Thesis, Faculty of the Fritz J. and Dolores H. Russ, College of Engineering and Technology, Ohio University, USA (2004).

24. Jungwirth, J.: Under-spanned Bridge Structures in Reactive Powder Concrete, 4th International Ph.D. Symposium in Civil Engineering, Munich, Germany (2002).

25. Yazici, H., Yardimci, M.Y., Aydın, S., Karabulut, A.S.: Mechanical properties of reactive powder concrete containing mineral admixtures under different curing regimes, Construction and Building Materials 23, 1223-1231 (2009).

26. Maroliya, M.K., Modhera, C.D.: A Comparative Study of Reactive Powder Concrete Containing Steel Fibers and Recron $3 S$ Fibers, Journal of Engineering Research and Studies 1(1), 83-89 (2010).

27. Hong, K.N., Kang, S.T., Kim, S.W., Park, J.J., Han, S.H.: Material properties of air-cured ultrahigh-performance steel-fiber-reinforced concrete at early ages, International Journal of the Physical Sciences 5(17), 2622-2634 (2010). 